\title{
Heterosiklik 4,5-dihidro-1H-1,2,4-triazol-5-on Türevinin Antioksidan Özelliğinin Erkek Ratlarda (Wistar albino) İn vivo Olarak Belirlenmesi
}

\author{
Evren $\mathrm{KOÇ}^{1 *}$, Haydar YÜKSEK ${ }^{2}$, Murat BEYTUR ${ }^{2}$, Onur AKYILDIRIM ${ }^{3}$, \\ Mustafa AKÇAY ${ }^{4}$, Cansu BEYTUR ${ }^{1}$ \\ ${ }^{1}$ Kafkas Üniversitesi, Mühendislik Mimarllk Fakültesi, Biyomühendislik Bölümü, Kars, Türkiye \\ ${ }^{2}$ Kafkas Üniversitesi, Fen-Edebiyat Fakültesi, Kimya Bölümü, Kars, Türkiye \\ ${ }^{3}$ Kafkas Üniversitesi, Mühendislik Mimarlık Fakültesi, Kimya Mühendisliği Bölümü, Kars, Türkiye \\ ${ }^{4}$ Kafkas Üniversitesi, Kars Meslek Yüksekokulu, Kimya ve Kimyasal Işsleme Teknolojileri Bölümü, Kars, Türkiye \\ (ORCID ID: 0000-0002-0022-9433) (ORCID ID: 0000-0003-1289-1800) (ORCID ID: 0000-0002-7098-5592) \\ (ORCID ID: 0000-0003-1090-695X)(ORCID ID: 0000-0003-1747-2314) (ORCID ID: 0000-0002-4361-5035)
}

\section{$\ddot{\mathbf{O} z}$}

4,5-Dihidro-1H-1,2,4-triazol-5-on türevli heterosiklik bileşikler sanayide, tıpta, eczacıllkta ve kimyanın pek çok alanında önemli yere sahiptir. Bu bileşiklerin bazı biyolojik aktivite özellikleri in vitro olarak incelenmiş olup bazılarının yüksek aktivite gösterdikleri belirlenmiştir. Bu aktivitelerden biri de 1,2,4-triazol-5-on türevlerinin göstermiş olduğu antioksidan özelliğidir. Mevcut araştırmada da, 3-metil-4-(3,4-dihidroksibenzilidenamino)-4,5dihidro-1H-1,2,4-triazol-5-on (3-MTA) bileşiğinin antioksidan özellik gösterip göstermediği ratlarda in vivo olarak spektrofotometrik yöntemle belirlenmiştir. Bu amaçla hayvanlar; kontrol grubu, dimetil sülfoksit (DMSO) grubu, $10 \mathrm{mg} / \mathrm{kg}$ ve $50 \mathrm{mg} / \mathrm{kg}$ 3-MTA bileşiği içeren gruplar olacak şekilde 4'e ayrılmıştır. Yapılan spektrofotometrik analizler neticesinde kontrol grubuna kıyasla serumda $10 \mathrm{ve} 50 \mathrm{mg} / \mathrm{kg}$ dozunda 3-MTA bileşiği uygulanan gruplarda $(\mathrm{P}<0.01)$, böbrek dokusunda ise $50 \mathrm{mg} / \mathrm{kg}$ dozunda 3-MTA bileşiği uygulanan grupta total antioksidan düzeyleri (TAD) artış göstermiştir $(\mathrm{P}<0.001)$. Bununla birlikte; böbrek dokusu total oksidan düzeyinin (TOD) ise kontrol grubuna göre $50 \mathrm{mg} / \mathrm{kg}$ 3-MTA bileşiği uygulanan grupta azaldığı belirlenmiştir $(\mathrm{P}<0.05)$. Sonuç olarak; elde edilen verilere göre, 3-MTA bileşiğinin sıçanlarda uygulanan doz ve sürede toksik etki göstermediği, serum ve böbrek TAD düzeyindeki artış ve böbrek TOD düzeyindeki azalmaya göre de olumlu biyolojik aktiviteye sahip olduğu kanısına varılmıştır.

Anahtar kelimeler: Triazol, Schiff bazı, TAD, TOD.

\section{In vivo Determination of Antioxidant Properties of Heterocyclic 4,5- dihydro-1H-1,2,4-triazole-5-one Derivative in Male Rats (Wistar albino)}

\begin{abstract}
4,5-Dihydro-1 $H$-1,2,4-triazol-5-one derived heterocyclic compounds have an important place in industry, medicine, pharmacy and many other fields of chemistry. Biological activity properties of these compounds have been examined in vitro, it was determined that some of them show high activity. One of these activities is the antioxidant property of 1,2,4-triazol-5-one derivatives. In the present study, the antioxidant properties of 3-methyl4-(3,4-dihydroxybenzylideneamino)-4,5-dihydro- $1 H$-1,2,4-triazol-5-one (3-MTA) were determined in rats by spectrophotometric method in vivo. For this purpose, animals were divided into 4 groups; control group, dimethyl sulfoxide (DMSO) group, $10 \mathrm{mg} / \mathrm{kg}$ and $50 \mathrm{mg} / \mathrm{kg}$ including MTA compound groups. As a result of the spectrophotometric analyzes, total antioxidant status (TAS) were increased in the serum treated groups of both 3MTA compounds $(\mathrm{P}<0.01)$ and in the renal tissue treated with only $50 \mathrm{mg} / \mathrm{kg}$ 3-MTA compounds $(\mathrm{P}<0.001)$. On the other hand, total oxidant status (TOS) of kidney tissue was decreased in $50 \mathrm{mg} / \mathrm{kg}$ 3-MTA compound administrated group compared to control group $(\mathrm{P}<0.05)$. As a result; according to the obtained data, it was concluded that 3-MTA compound did not show toxic effects in dose and duration of rats and it had positive biological activity according to increase in serum and renal TAS levels and decrease in renal TOS levels.
\end{abstract}

Keywords: Triazole, Schiff base, TAS, TOS.

*Sorumlu yazar: evrenkoc@hotmail.com.tr

Geliş Tarihi: 02.08.2019, Kabul Tarihi: 06.12.2019 


\section{Giriş}

Reaktif oksijen türleri (ROT) normal fizyolojik süreçlerde ya da patolojik durumlarda oluşan çok küçük yapılı moleküller olup, organizmadaki birçok bileşen ile kolayca kimyasal reaksiyona girebilmektedir [1]. ROT'un aşırı üretimi ve oksidan/antioksidan dengenin oksidanlar lehine bozulduğu durumlarda oksidatif stres meydana gelmektedir [2]. Antioksidanlar ise, oksidatif strese sebep olan ROT'u kararl bileşikler haline dönüştürerek organizmadaki zararlı etkilerini ortadan kaldırmaktadırlar [3]. Doğal antioksidanların yanı sıra son zamanlarda sentetik antioksidanlar da dikkat çekmektedir [4]. Schiff bazları genel olarak bir amino bileşiği ile karbonil grubuna sahip bileşiklerin reaksiyonu sonucu oluşan imin gruplu bileşiklerdir [5]. Son y1llarda özellikle biyo-organik kimya alanındaki gelişmelere bağlı olarak oldukça biyoaktif maddeler olan ve antibakteriyel, antifungal [6], antitümör [7,8], antioksidan [5,9] özelliklerinin yanı sıra metallerle kompleks oluşturma kabiliyetine de sahip Schiff bazlı bileşikleri de içeren makrosiklik bileşiklere olan ilgi artmıştır [10]. 1,2,4-triazol halkası heterosiklik bir bileşik olarak kabul edilmektedir, kapalı formülü $\mathrm{C}_{2} \mathrm{H}_{3} \mathrm{~N}_{3}$ 'tür. Molekül formülünde de görüldüğü gibi, 2 karbon ve 3 azot atomu içermektedir. $1 H$ ve $4 H-1,2,4$-triazol halkası, farmakolojik olarak önemli sayılabilecek bir çekirdektir [11].

Mevcut araştırmada, antioksidan özelliği in vitro olarak belirlenen 5 üyeli 1,2,4-triazol grubu içeren heterosiklik Schiff bazı bileşiği olan 3-MTA'nın ratlarda antioksidan/oksidan sistem üzerine etkisi in vivo olarak araştırılmıştır.

\section{Materyal ve Metot}

\subsection{Bileşiğin Sentezi}

Araştırmada kullanılan 3-metil-4-(3,4-dihidroksibenzilidenamino)-4,5-dihidro-1H-1,2,4-triazol-5-on (3-MTA) (Şekil 1) bileşiğinin sentezi Yüksek ve ark. (2006)'nın belirttiği yönteme göre sentezlenmiştir [12].

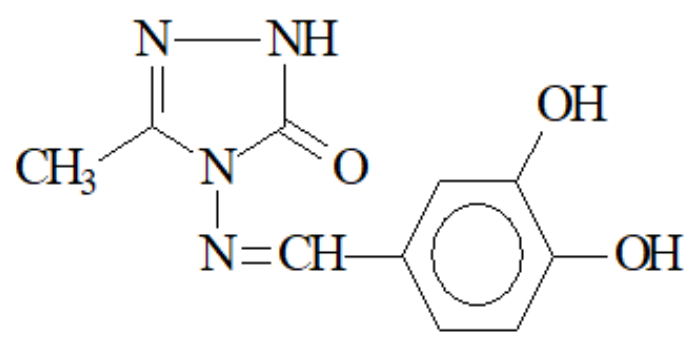

Şekil 1. 3-MTA'nın kimyasal yapısı [12]

\subsection{Deneysel Dizayn}

Çalışmada hayvan materyali olarak 4-5 aylık, erkek Rat (Wistar albino) kullanılmıştır. Çalışma ile ilgili olarak Kafkas Üniversitesi Hayvan Deneyleri Yerel Etik Kurulundan çalışma izni alınmıştır (Sayı: 2018/030-2019/53). Hayvanlar deney öncesi ve deney esnasinda $25 \pm 2^{\circ} \mathrm{C}$ sicaklıkta, $\%$ 60-65 düzeyinde nemli ortamlarda ve 12 saat aydınlık ve 12 saat karanlık döngüsünün sağlandığı koşullarda, ad-libitum olarak beslenmiştir. Hayvanlar her grupta 7 adet rat olacak şekilde 4 gruba ayrılmıştır.

I. gruptaki hayvanlar kontrol grubu olarak belirlenmiş ve intraperitonal yolla 7 gün süreyle 0.1 $\mathrm{ml}$ serum fizyolojik uygulanmıştır.

II. gruptaki hayvanlar DMSO grubu olarak belirlenmiş ve intraperitonal yolla 7 gün süreyle 0.1 $\mathrm{ml} \% 25$ 'lik DMSO uygulanmıştır.

III. ve IV. gruptaki hayvanlara ise \%25'lik DMSO'da çözünen 3-MTA bileşiğinden hazırlanan solüsyondan 7 gün süreyle sırasıyla $10 \mathrm{mg} / \mathrm{kg}$ ve $50 \mathrm{mg} / \mathrm{kg}$ intraperitonal olarak uygulanmıştır [13]. 


\subsection{Biyokimyasal Analizler}

Deney süresi sonunda hayvanlar dekapite edilerek kan ve doku örnekleri alınmıştır. Kan örnekleri santrifüj edilerek serumlarının ayrılması sağlanmış, doku örnekleri de potasyum fosfat tamponu (50 $\mathrm{mM}, \mathrm{pH}$ 7.8) ile 1:10 (ağırlık/hacim) sulandırılarak buz üzerinde homojenize edilmiş ve 30 dakika 4.500 rpm ve $4{ }^{\circ} C^{\prime}$ de santrifüj edilerek süpernatant kısımlarının ayrılması sağlanmıştır. Serum ve homojenatların oksidan/antioksidan kapasiteleri Total Antioxidant Status ve Total Oksidan Status Assay kitler (Rel Assay Diagnostics, Clinical Chemistry Solutions, Gaziantep, Turkey) kullanılarak spektrofotometrik yöntemle belirlenmiştir.

\section{4. İstatistiksel Analizler}

İstatistiksel analizler için SPSS 22 paket programı kullanılmıştır. Elde edilen verilerde grupların normal dağılım gösterip göstermedikleri Shapiro Wilk-W testi kullanılarak belirlenmiştir. İstatistik hesaplamalarda tek yönlü varyans analizi (One-way ANOVA) kullanılmıştır. Gruplar arası farklılığ belirlemek amacıyla Tukey testi uygulanmıştır ve $\mathrm{P}<0.05$ istatistiksel olarak önemli kabul edilmiştir.

\section{Bulgular ve Tartışma}

Yapılan analizler neticesinde serum total antioksidan düzeylerinin kontrol grubuna kıyasla 10 ve 50 $\mathrm{mg} / \mathrm{kg}$ dozunda 3-MTA bileşiği uygulanan gruplarda artı̧̧ gösterdiği saptanmıştır $(\mathrm{P}<0.01)$ (Tablo 1). Karaciğer ve kalp dokularından elde edilen homojenatların spektroskopik incelemeleri sonucunda ise kontrol ve uygulama grubu hayvanların total antioksidan seviyelerinde istatistiksel olarak farklilik tespit edilmemiştir $(\mathrm{P}>0.05)$. Benzer şekilde böbrek dokusu homojenatlarının analizlerinde ise kontrol grubu ile 3-MTA bileşiği uygulanan gruplar kıyaslandığında, $50 \mathrm{mg} / \mathrm{kg}$ 3-MTA bileşiği uygulanan grupta total antioksidan seviyede istatistiksel olarak anlamlı artış meydana geldiği belirlenmiştir $(\mathrm{P}<0.001)$ (Tablo 2). Total oksidan seviyeler açısından kıyaslama yapıldığında ise serum (Tablo 1) ile karaciğer ve kalp dokusu (Tablo 3) homojenatlarının analizlerine göre kontrol ve uygulama grupları arasında istatistiksel olarak bir farklılık tespit edilmemiştir $(\mathrm{P}>0.05)$. Ancak böbrek doku örneklerinin analizlerine göre, kontrol grubuna kıyasla $10 \mathrm{mg} / \mathrm{kg}$ ve $50 \mathrm{mg} / \mathrm{kg}$ 3-MTA bileşiği içeren gruplardaki total oksidan seviyenin azaldığı, sadece $50 \mathrm{mg} / \mathrm{kg}$ 3-MTA bileşiği içeren gruptaki düşüşün kontrol grubuna göre istatistiksel olarak anlamlı olduğu gözlemlenmiştir $(\mathrm{P}<0.05)$ (Tablo 3).

Tablo 1. Gruplara ait serum TAD ve TOD seviyeleri

\begin{tabular}{|c|c|c|}
\hline & $\begin{array}{c}\text { TAD } \\
\text { (mmolTrolox Equiv./L) }\end{array}$ & $\begin{array}{c}\text { TOD } \\
\left(\mu \mathrm{mol} \mathrm{H}_{2} \mathrm{O}_{2} \text { Equv./L) }\right.\end{array}$ \\
\hline Kontrol & $0.37 \pm 0.07^{\mathrm{b}}$ & $6.00 \pm 0.63$ \\
\hline DMSO & $0.70 \pm 0.23^{\mathrm{ab}}$ & $6.67 \pm 1.36$ \\
\hline $10 \mathrm{mg} / \mathrm{kg}$ 3-MTA & $0.91 \pm 0.26^{\mathrm{a}}$ & $6.77 \pm 0.97$ \\
\hline $50 \mathrm{mg} / \mathrm{kg}$ 3-MTA & $0.80 \pm 0.25^{\mathrm{a}}$ & $6.47 \pm 0.90$ \\
\hline
\end{tabular}

* Aynı sütunda farklı harfler istatistiksel farklılı̆̆ı göstermektedir (Kontrol grubuna kıyasla) $(\mathrm{P}<0.01)$ 
Tablo 2. Karaciğer, kalp, böbrek dokularına ait TAD seviyeleri (mmolTrolox Equiv./g doku)

\begin{tabular}{lccc}
\cline { 2 - 4 } & Karaciğer & Kalp & Böbrek \\
\hline Kontrol & $4.40 \pm 1.04$ & $6.43 \pm 1.73$ & $4.10 \pm 0.18^{\mathrm{b}}$ \\
DMSO & $4.22 \pm 1.32$ & $7.29 \pm 0.39$ & $4.27 \pm 0.35^{\mathrm{b}}$ \\
$\mathbf{1 0} \mathbf{~ m g / k g ~ 3 - M T A}$ & $5.05 \pm 0.37$ & $6.43 \pm 1.05$ & $7.32 \pm 1.67^{\mathrm{ab}}$ \\
$\mathbf{5 0} \mathbf{~} \mathbf{m g} / \mathbf{k g} 3-M T A$ & $5.35 \pm 1.34$ & $7.41 \pm 1.22$ & $9.01 \pm 2.41^{\mathrm{a}}$ \\
\hline
\end{tabular}

* Aynı sütunda farklı harfler istatistiksel farklılığı göstermektedir (Kontrol grubuna kıyasla) $(\mathrm{P}<0.001)$

Tablo 3. Serum ve karaciğer, kalp, böbrek dokularına ait TOD seviyeleri ( $\mu$ mol $\mathrm{H}_{2} \mathrm{O}_{2}$ Equv./g doku)

\begin{tabular}{|c|c|c|c|}
\hline & Karaciğer & Kalp & Böbrek \\
\hline Kontrol & $24.90 \pm 4.24$ & $19.11 \pm 4.01$ & $41.84 \pm 2.22^{\mathrm{a}}$ \\
\hline DMSO & $24.12 \pm 3.76$ & $21.62 \pm 5.80$ & $42.91 \pm 2.34^{\mathrm{a}}$ \\
\hline 10 mg/kg 3-MTA & $27.09 \pm 3.29$ & $19.54 \pm 3.33$ & $40.59 \pm 4.55^{\mathrm{ab}}$ \\
\hline $50 \mathrm{mg} / \mathrm{kg}$ 3-MTA & $27.17 \pm 4.95$ & $22.40 \pm 7.59$ & $37.36 \pm 2.62^{b}$ \\
\hline
\end{tabular}

* Aynı sütunda farklı harfler istatistiksel farklılı̆̆ı göstermektedir (Kontrol grubuna kıyasla) $(\mathrm{P}<0.05)$

Yapılan bu araştırmada 3-MTA bileşiğinin ratlarda antioksidan/oksidan seviye üzerine etkileri araştırılmıştır. Son zamanlarda, Schiff bazı bileşiklerin kimyasal yapılarından dolayı bu bileşikler ile ilgili çalışmalar artış göstermiştir. Yapılan bir araştırmaya göre tiyosemikarbazon türevli Schiff bazı bileşiklerinin önemli bir serbest radikal süpürücü özelliğe sahip olduğu bildirilmiştir [14]. Benzer şekilde 1,2,4-triazol ve pirazol halkaları içeren iki Schiff bazının güçlü antioksidan ajan olduğu belirtilmektedir [3]. Dorovic ve ark. (2019) yapmış oldukları araştırmada 1,2,4-triazol-3-tiyon bileşiğinin yapısında bulunan $\mathrm{OH}$ grupları sayesinde güçlü serbest radikal süpürücü etkiye sahip olduğunu bildirmişlerdir [4]. Iqbal ve ark. (2019) bikarbazol bağlı triazollerin reaktif oksijen türlerinin etkilerini azalttığını, biyolojik özellikleri ayarlamak, iltihapları ve ilgili dejeneratif problemleri kontrol etmek için önemli bir yapısal unsur olabileceğini belirtmişlerdir [15]. 3-Aminotriazol bileşiğinin farelerde kobalt klorür ile oluşturulan toksisiteye karşı ROT üretimini ve pro-inflamatuar sitokin üretimini azalttığ 1 bildirilmiştir [16].

Araştırmada kullanılan 3-MTA bileşiğinin in vitro olarak antioksidan özellik gösterdiği [12] ve bu tür bileşiklerin yapısal özelliklerinden dolayı tıp ve eczacılık gibi birçok alanda yaygın şekilde kullanıldığ 1 belirtilmektedir [17]. Ancak preklinik olarak bu maddelerin etkilerinin açıkça ortaya konması gerekmektedir. $\mathrm{Bu}$ nedenle de birçok araştırmacı böyle bileşiklerin etkilerini belirlemek amacıyla deneysel olarak farklı çalışmalar ortaya koymuşlardır. Yapılan bir araştırmada triazol iskeleti içeren bileşiğin sıçanlarda oluşturulan meme kanseri modelinde herhangi bir toksik özellik göstermediği, tümör gerilemesine ve tümörlü hücrelerin azalmasına yol açtığı belirtilmiştir [8]. Parlak ve ark. (2015) 2,4-dihidro-3H-1,2,4-triazol-3-tiyon türevinin ratlarda antioksidan vitamin C seviyesini artırdığını, malondialdehit (MDA) seviyesini ise azalttığını tespit etmişler ve uygulanan bu bileşiğin gösterdiği antioksidan aktivitenin, triazol halkasına bağlanan ve biyolojik aktivite gösteren benzilpiperazin grubundan kaynaklı olduğunu belirtmişlerdir [11]. Başka araştırmacılar da, yeni sentezlenen bazı triazol türevlerinin farelerde solunum yolu enfeksiyonlarına karşı reaktif oksijen türlerinin oluşumu ve pro-enflamatuar sitokin ekspresyonunu inhibe ettiğini belirtmişlerdir [18]. Yine benzer şekilde, yeni bir Schiff baz türevi kobalt(II)-kompleksinin antioksidan özelliklerinin araştırıldığ1 bir araştırmada glutatyon peroksidaz (GPx), süperoksit dismutaz (SOD) seviyelerinde anlamlı bir artış ve MDA'da bir düşüş gözlemlemişlerdir. Bununla birlikte karaciğer ve böbrek dokularında histolojik inceleme neticesinde kontrol grubuna kıyasla bir değişiklik tespit edilmediği bildirilmiştir [19]. Başka 
bir çalışmada da, sıçanlarda oluşturulan gastrik ülsere karşı yeni Schiff bazı türevi mangan(II)kompleksinin etkisi araştırılmış ve Schiff bazlı kompleks uygulanan gruplarda SOD seviyesinin arttığı, MDA seviyesinin azaldığ tespit edilmiş̧ir. Yine benzer şekilde bu çalışmada da karaciğer ve böbrek dokularında histolojik olarak farklılık meydana gelmediği bildirilmiştir [5]. Mevcut araştırmada da kontrol grubuna kıyasla serumda $10 \mathrm{mg} / \mathrm{kg}$ ve $50 \mathrm{mg} / \mathrm{kg}$ 3-MTA bileşiği uygulan gruplarda, böbrek dokusunda ise $50 \mathrm{mg} / \mathrm{kg}$ 3-MTA bileşiği uygulan grupta total antioksidan seviyenin artış gösterdiği saptanmıştır. Bununla beraber, böbrek dokusu total oksidan seviyenin de $50 \mathrm{mg} / \mathrm{kg}$ 3-MTA bileşiği uygulanan grupta azaldığı belirlenmiştir.

\section{Sonuç ve Öneriler}

Elde edilen sonuçlara göre kullanılan heterosiklik Schiff bazı türevi olan 3-MTA bileşiği hayvanlarda toksik bir etki göstermemiş, serum ve böbrek dokusunda total antioksidan seviyeyi artırırken sadece böbrek dokusunda total oksidan seviyeyi düşürmüsstür. Total antioksidan seviyelerde meydana gelen artışın, uygulanan 3-MTA bileşiği ile antioksidan enzimler arasında moleküller arası hidrojen bağları oluşarak, 3-MTA bileşiğine bağlı olarak antioksidan enzim seviyesini yükselttiği düşünülmektedir. Ayrıca sadece böbrek dokusu total oksidan seviyenin azalmış olmasının nedeni, farklı çalışmalarla belirlenmelidir. Özellikle böbrekler üzerindeki bu etkisi saptandığı takdirde, ROT’a bağl1 olarak gelişen nefropatik semptomların ortadan kaldırılması bakımından da umut verici sonuçlar elde edilebileceği düşünülmektedir.

\section{Teşekkür}

Bu çalı̧̧ma Kafkas Üniversitesi Bilimsel Araştırma Projeleri Komisyonu tarafından desteklenmiştir (BAP Proje No: 2018-FM-73).

\section{Yazarların Katkısı}

Araştırma ile ilgili hipotezin kurulmasında, literatür araştırmasında, hayvanlar üzerinde uygulamaların yapılmasında, analiz ve hesaplamaların yapılmasında ve makalenin yazımında Evren KOÇ, 3-MTA bileşiğinin sentezinde ve yapı aydınlatmasında Haydar YÜKSEK, Murat BEYTUR, Onur AKYILDIRIM, literatür araştırmasında ve analizlerin yapılmasında Mustafa AKÇAY ve Cansu BEYTUR katkı sağlamışlardır.

\section{Çıkar Çatışması Beyanı}

Yazarlar arasında çıkar çatışması bulunmamaktadır.

\section{Araştırma ve Yayın Etiği Beyanı}

Çalışmada araştırma ve yayın etiğine uyulmuştur. Çalışma ile ilgili olarak Kafkas Üniversitesi Hayvan Deneyleri Yerel Etik Kurulu’ndan çalışma izni alınmıştır (Sayı: 2018/030-2019/53).

\section{Kaynaklar}

[1] Atashi F., Modarressi A., Pepper M.S. 2015. The Role of Reactive Oxygen Species in Mesenchymal Stem Cell Adipogenic and Osteogenic Differentiation: A Review. Stem Cells and Development, 24 (10): 1150-1163.

[2] Ihsan A.U., Khan F.U., Khongorzul P., Ahmad K.A., Naveed M., Yasmeen S., Cao Y., Taleb A., Maiti R., Akhter F. 2018. Role of Oxidative Stress in Pathology of Chronic Prostatitis/Chronic Pelvic Pain Syndrome and Male Infertility and Antioxidants Function in Ameliorating Oxidative Stress. Biomedicine \& Pharmacotherapy, 106: 714-723.

[3] Pillai R.R., Karrouchi K., Fettach S., Armaković S., Armaković S.J., Brik Y., Taoufik J., Radi S., Faouzi M.E.A., Ansar M. 2019. Synthesis, Spectroscopic Characterization, Reactive Properties 
by DFT Calculations, Molecular Dynamics Simulations and Biological Evaluation of Schiff Bases Tethered 1,2,4-Triazole and Pyrazole Rings. Journal of Molecular Structure, 1177: 47-54.

[4] Đorović J., Milenković D., Joksović L., Joksović M., Marković Z. 2019. Study of Influence of Free Radical Species on Antioxidant Activity of Selected 1,2,4-triazole-3-thiones. Chemistry Select, 4 (25): 7476-7485.

[5] Ibrahim M.Y., Hashim N.M., Dhiyaaldeen S.M., Al-Obaidi M.M.J., El-Ferjani R.M., Adam H., Alkotaini B., Al Batran R., Ali H.M. 2016. Acute Toxicity and Gastroprotection Studies of A New Schiff Base Derived Manganese(II) Complex Against Hcl/Ethanol-Induced Gastric Ulcerations in Rats. Scientific Reports, 6: 26819.

[6] Kahveci B., Özil M., Menteşe E., Bekircan O., Buruk K. 2008. Microwave-Assisted Synthesis and Antifungal Activity of Some New $1 H-1,2,4$-triazole Derivatives. Russian Journal of Organic Chemistry, 44 (12): 1816-1820.

[7] Demirbaş N., Ugurluogłu R., Demirbaş A. 2002. Synthesis of 3-alkyl(aryl)-4-alkylidenamino-4, 5-dihydro-1 $\mathrm{H}$-1,2,4-triazol-5-ones and 3-alkyl-4-alkylamino-4,5-dihydro-1 $\mathrm{H}$-1,2,4-triazol-5ones as Antitumor Agents. Bioorganic \& Medicinal Chemistry, 10 (12): 3717-3723.

[8] Saini K.S., Ajay A., Devender N., Bhattacharjee A., Das S., Dwivedi S., Gupt M.P., Bora H.K., Mitra K., Tripathi R.P. 2015. Triazole Analog 1-(1-benzyl-5-(4-chlorophenyl)-1H-1,2,3-triazol4-yl)-2-(4-bromophenylamino)-1-(4-chlorophenyl) Ethanol Induces Reactive Oxygen Species and Autophagy-Dependent Apoptosis in both In vitro and In vivo Breast Cancer Models. The International Journal of Biochemistry \& Cell Biology, 65: 275-287.

[9] Arslantas A., Yüksek H., Gürsoy Kol Ö., Ocak Z., Tomruk Z., Calapoglu M. 2012. Study of Antioxidant Properties and DNA Interaction of Some Novel 4, 5-dihydro-1H-1, 2, 4-triazol-5one Derivatives. Asian Journal of Chemistry, 24 (8): 3327-3334.

[10] Zayed E.M., Zayed M.A., El-Desawy M. 2015. Preparation and Structure Investigation of Novel Schiff Bases Using Spectroscopic, Thermal Analyses and Molecular Orbital Calculations and Studying Their Biological Activities. Spectrochimica Acta Part A: Molecular and Biomolecular Spectroscopy, 134: 155-164.

[11] Parlak A.E., Çelik S., Karatepe M., Koparır M. 2015. The Effects of 5,5'-butane-1,4-diylbis\{2[(4-benzylpiperazin-1-yl)methyl]-4-ethyl-2,4-dihydro-3H-1,2,4-triazole-3-thione\} on MDA Level and Vitamins in Serum, Liver and Kidney of Rats. NWSA-Physical Sciences, 10 (2): 2936.

[12] Yüksek H., Kolaylı S., Küçük M., Yüksek M.Ö., Ocak U., Şahinbaş E., Sivrikaya E., Ocak M. 2006. Synthesis and Antioxidant Activities of Some 4-benzylidenamino-4,5-dihydro- $1 \mathrm{H}-1,2,4-$ triazol-5-one Derivatives. Indian Journal of Chemistry, 45B: 715-718.

[13] Chigurupati S., Shaikh S.A., Mohammad J.I., Selvarajan K.K., Nemala A.R., Khaw C.H., Teoh C.F., Kee T.H. 2017. In vitro Antioxidant and In vivo Antidepressant Activity of Green Synthesized Azomethine Derivatives of Cinnamaldehyde. Indian Journal of Pharmacology, 49 (3): 229235.

[14] Al-Amiery A.A., Al-Majedy Y.K., Ibrahim H.H., Al-Tamimi A.A. 2012. Antioxidant, Antimicrobial, and Theoretical Studies of The Thiosemicarbazone Derivative Schiff Base 2-(2imino-1-methylimidazolidin-4-ylidene) hydrazinecarbothioamide (IMHC). Organic and Medicinal Chemistry Letters, 2 (4).

[15] Iqbal S., Khan M.A., Ansari Z., Jabeen A., Faheem A., Fazal-Ur-Rehman S., Basha F.Z. 2019. Synthesis of New Bicarbazole-Linked Triazoles as Non-Cytotoxic Reactive Oxygen Species (ROS) Inhibitors. Synthetic Communications, 49 (18): 2330-2341.

[16] Lee J.N., Kim S.G., Lim J.Y., Dutta R.K., Kim S.J., Choe S.K., So H.S., Park R. 2016. 3Aminotriazole Protects From $\mathrm{CoCl}_{2}$-Induced Ototoxicity by Inhibiting the Generation of Reactive Oxygen Species and Proinflammatory Cytokines in Mice. Archives of Toxicology, 90 (4): 781 791.

[17] Karthikeyan M.S., Prasad D.J., Poojary B., Bhat K.S., Holla B.S., Kumari N.S. 2006. Synthesis and Biological Activity of Schiff and Mannich Bases Bearing 2,4-dichloro-5-fluorophenyl Moiety. Bioorganic \& Medicinal Chemistry, 14 (22): 7482-7489.

[18] Zhang C., Li N., Niu F. 2019. Baicalein Triazole Prevents Respiratory Tract Infection by RSV Through Suppression of Oxidative Damage. Microbial Pathogenesis, 131: 227-233. 
[19] El-Ferjani R.M., Ahmad M., Dhiyaaldeen S.M., Harun F.W., Ibrahim M.Y., Adam H., Yamin B.M., Al-Obaidi M.M.J., Al Batran R. 2016. In vivo Assessment of Antioxidant and Wound Healing Improvement of A New Schiff Base Derived Co(II) Complex in Rats. Scientific Reports, 6: 38748 